\section{Rotavirus and Adenovirus Positivity in Child Diarrhoea in a Tertiary Hospital}

\section{Rıdvan Guckan', Cetin Kılınc', Osman Aydin'1, Zeynep Hulya Durmaz ${ }^{1}$, Aslihan Dilara Demir ${ }^{1}$, Gökce Celep ${ }^{1}$ and Keramet- tin Yanik ${ }^{2 *}$}

'Sabuncuoğlu Serafeddin Education and Research Hospital, Amasya University, Amasya, Turkey

${ }^{2}$ Department of Medical Microbiology, Faculty of Medicine, Ondokuz Mayıs University, Samsun, Turkey

\begin{abstract}
Rotavirus and Adenovirus are the majority of the viral factors of acute gastroenteritis which is responsible for child mortality. These viruses are the most common reasons for the viral gastroenteritis in children aged 6-24 months. The aim of this study is to determine the age, seasonal distribution and the positivity rate of Rotavirus and Adenovirus infections among children with diarrhea who were admitted to a tertiary care education and research hospital. The 5412 children (2992 (55\%) male and 2420 female (45\%)) between the ages of 0-6 were included in the study. The data of them were obtained retrospectively between January 2013 and January 2015 from the results of laboratory reports. Rotavirus $\mathrm{Ag}$ in 395 (7.2\%) and Adenovirus Ag in $20(0.36 \%)$ of the patients were studied and 7 $(0.12 \%)$ of them were determined as positive for both factors. It was determined that Rotavirus positivity was higher in patients during the colder months compared to others. Positive cases were observed mostly in children between the ages of 0 and 2, followed by the group of children who were 1-year old. As a result, clinician should remember rotavirus infections in pediatric gastroenteritis which are observed particularly in winter, according to the distinctive diagnosis. It is decided that Rotavirus Ag-ELISA tests are applicable and sensitive in the diagnosis of the Rotavirus infection. Thus, unnecessary antibiotic usage can be prevented with the help of a sensitive diagnosis of the infection.
\end{abstract}

Keywords: Gastroenteritis; Positivity; Rotavirus; Season and age

*Corresponding author: Keramettin Yanik, Department of Medical Microbiology, Faculty of Medicine, Ondokuz Mayıs University, Tip Fak Itesi, 55139 Kurupelit, Samsun, Turkey, Tel: +90 5072329215; Fax: +90 3624576091; E-mail: keramettinyanik@omu.edu.tr

Citation: Guckan R, Kılınc C, Aydin O, Durmaz ZH, Demir AD, et al. (2015) Rotavirus and Adenovirus Positivity in Child Diarrhoea in a Tertiary Hospital. $J$ Infect Non Infect Dis 1: 007.

Received: June 10, 2015; Accepted: September 22, 2015; Published: October 06,2015

\section{Introduction}

Gastroenteritis causes death of 5-10 million children per year [1]. Viral gastroenteritis is among the second most common diseases observed in developed countries [2]. Rotavirus, which is a genus in the Reoviridae family, is an important factor for the society-derived and nosocomial acute infectious gastroenteritis observed in the early childhood [1]. It causes viral gastroenteritis which might lead to serious clinical mortality, especially in children aged 6-24 months $[1,3,4]$. Except the Rotavirus and Adenoviruses, which are also common factors for diarrhea, are usually detected as the gastroenteritis factor in children younger than 2 years old and these viruses may also cause infections such as conjunctivitis cystitis and meningoencephalitis. Rota virus infections are frequently observed during the cold seasons. Infections are generally transmitted orally and faecally and the resistance to disinfectants makes the contamination much easier [4-6]. As the clinical findings are non-specific, the certain diagnosis can be made with laboratory examinations. Laboratory tests are very important in the diagnosis. imaging methods such as electron microscopy, cell culture techniques, serological tests and the detection methods for antigens and nucleic acids can be used in the exact diagnosis. Besides, chromatographic immunoassays are rapid, inexpensive, highly sensitive and easy serological tests. The test should be easy, fast, cheap and highly sensitive. In order to diagnose the viral gastroenteritis, the incidence of infectious pathogens and factors affecting them should be determined by performing surveillance studies since effective treatment methods have not yet been developed. Epidemiological surveillance and the control of viral gastroenteritis is very crucial due to the lack of effective treatments and unnecessary use of antibiotics [4,5].

The aim of this study is to reveal the positivity of the infection as well as the seasonal differences according to the age distribution by detecting Rotavirus Ag and Adenovirus Ag in stool samples of the patients between the ages of 0-6 with diarrhea using ELISA technique.

\section{Material and Methods}

Retrospective data were obtained from patients who were diagnosed with an acute gastroenteritis and admitted to several clinics of Sabuncuoğlu Serafeddin Education and Research Hospital in Amasya, in the North coast of Turkey, between January 2013 and January 2015. This hospital is in the middle of the Blacksea region, in Turkey. We accepted only one specimen per patient. 5412 stool specimens were examined in microbiology laboratory between January 2013 and January 2015. The fresh stool samples were tested by using Rotavirus and Adenovirus antigen tests (Xiamen, Boson Biotech Co. Ltd., China) according to manufacturers' instructions. This test is a combo test which is a rapid chromatographic immunassay for the qualitative detection of rotavirus and adenovirus antigens in human faeces samples. Rapid Adeno/Rota Virus Antigen Combo Test is a sandwich solid phase immunochromatographic assay. To perform the test, an aliquot of diluted stool sample is added to the sample well of the test cassette. The sample flows through a pad containing antibodies against adenovirus and rotavirus coupled 
Citation: Guckan R, Kllınc C, Aydin O, Durmaz ZH, Demir AD, et al. (2015) Rotavirus and Adenovirus Positivity in Child Diarrhoea in a Tertiary Hospital. J Infect Non Infect Dis 1:007.

\begin{tabular}{|c|c|c|c|c|c|c|c|}
\hline Viruses & Total (n) & 0-1 (\%) & $1-2(\%)$ & 2-3 (\%) & 3-4 (\%) & 4-5 (\%) & $5-6(\%)$ \\
\hline Rotavirus & 395 & $128(32.4)$ & $133(33.6)$ & $65(16.4)$ & $31(7.8)$ & $22(5.5)$ & $16(4)$ \\
\hline Adenovirus & 20 & $7(35)$ & $4(20)$ & $4(20)$ & $2(10)$ & $2(10)$ & $1(5)$ \\
\hline Rota-Adeno & 7 & $5(71.4)$ & $1(14.2)$ & $1(14.2)$ & - & - & - \\
\hline
\end{tabular}

Table 1: Distribution and percentages of Rotavirus and Adenovirus positive frequency compared to ages.

$\mathrm{n}$ - Samples number; \% - percent

to red-colored colloidal gold. If the sample contains adenovirus or rotavirus antigens, the antigen will bind to the antibody coated colloidal gold particles to form antigen-antibody-gold complexes. These complexes move on the nitrocellulose membrane by capillary action toward the test line region on which adenovirus and rotavirus specific antibodies are immobilized separately. As the complexes reach the test line, they will bind to the antibody corresponding to the virus on the membrane to create the line. A red control line will always appear in the result window to indicate that the test has been correctly performed and the test device functions properly. If virus is not present or lower than the detection limit of the test, only the control line will be visible. If the control line is not seen, the test is invalid. Test results were positively and negatively evaluated by comparing according to the control band. Test sensitivity and specificity has been reported as $98.2 \%$ and $97.8 \%$ for Rotavirus and $99 \%$ and $98 \%$ for Adenovirus by the manufacturer.

\section{Results}

A total of 5412 patients, 2992 (55\%) male and 2420 (45\%) female, between the ages of $0-6$, who were pre-diagnosed with acute gastroenteritis, were included in the study. $82 \%$ of the cases were admitted to outpatient clinics. Rotavirus was detected in 395 (7.29\%), Adenovirus was detected in $20(0.37 \%)$, and both viruses were detected in 7 (0.12\%) samples. Rotavirus was mostly observed in 128 patients (32.4\%) who were between 0-1 years old and in 133 patients who were between 1-2 years old (33.6\%). Adenovirus positivity was mostly seen in $0-1$ years of children (7 patients of 20; 35\%) (Table 1 ).

When we observed the seasonal changes in Rotavirus and Adenovirus positive cases, it was determined that Rotavirus positivity was found higher in winter compared to other seasons (173 patients of $395 ; 43.7 \%$ ) (Table 2). There was no significant seasonal difference between the positivity rates of the antigens of enteric Adenovirus and Rotavirus-Adenovirus.

\section{Discussion}

It is known that diarrhea leads to death in the $21 \%$ of children who are younger than 5 years old throughout the world and $8.4 \%$ of deaths are observed in children who are between the 0-14 years old in our country $[7,8]$. Rota virus causes diarrhea in the $10-20 \%$ of the cases in developing countries and even death of many patients every year $[3,4]$. Rotavirus is the most common reason for infectious diarrhea in children who are younger than 6 years old in the world. This virus, which causes severe diarrhea in 6-24 months old children, is particularly responsible for the $30-60 \%$ of the watery diarrhea. Rotavirus enteritis is an important reason for the morbidity and mortality in babies and children under the age of 2 in developing countries. Approximately $40-70 \%$ of diarrhea cases which require hospitalization are caused by Rotavirus. In addition, Rotaviruses constitute almost the half of the causative microrganisms of nosocomial gastroenteritis in babies between $0-2$ years old $[1,4]$.
According to the etiological research studies performed by Nazik et al., Rotavirus positivity in gastroenteritis patients, who live in Istanbul was 20.6\% [9], Kizirgil and Karakoc found that it was $31.9 \%$ in Elazig [10]. Besides, Borsa et al., detected Rotavirus positive cases in Mardin was 19.9\% [11], Gül et al., determined the Rotavirus positivity in Kahramanmaras was $25.7 \%$ [12]. Otag et al., found the Rotavirus infection in $28.6 \%$ of patients living in Mersin [13]. Yarkin and Torun detected Rotavirus infection in $21.8 \%$ of the patients in Adana [14]. In our study, Rotavirus positivity was detected in 395 patients of 5412 (7.29\%) children. According to our results, Rotavirus positivity rates were much lower than the rates found in other studies performed in Turkey. The difference in the rates may be related to the different kinds of the tests that are used to diagnose the disease, experience of the personnel conducting the test, time of disease, sample taking method, quality of the sample, season and the socio-economical conditions $[1,4]$. However, the use of rota vaccine, which has been applied for the last five years in our city, may play an important role in these low infection rates. Rotavirus vaccination has not yet been included in the childhood vaccination calendar in Turkey. Vaccination is optional and has also a certain fee. Thus, there is no data with respect to the number of patients who had received the rotavirus vaccine. According to the studies conducted in different parts of the world to determine the rotavirus positivity rates, it has been reported that the positivity rate is $16 \%$ in Germany [15], $17-69 \%$ in the United States of America [16], 20\% in Pakistan [17], and $11 \%$ in Kenya [18]. Ahlywalia et al., reported that the incidence of adenovirus gastroenteritis during the period of infancy was 4.1\% [19]. While Rotavirus positivity rates constituted the majority in 1-2 age groups with a rate of $33.6 \%$ (133) and $66 \%$ of the positive cases were between the 0 and 2 years old. In the studies performed by Hilmioglu et al. [20] with children aged in 0-1, by Asc1 et al., [21] with children aged in $0-2$, it has been detected that the Rotavirus positivity is higher than the other age groups. Furthermore, in many studies conducted in Turkey is in line with our study and this infection has been detected mostly in children between the ages of $0-2[9,22,23]$. In our study, there were 173 (43.7\%) positive cases in winter months.

According to the studies performed by Yunus Bulut et al., [8] in Malatya, Turkdagi et al., [24] in Konya, Balkan et al., [25] in Erzurum, Borsa et al., [11] in Mardin, Rota virus was detected most frequently in winter in Turkey. The reports obtained from the different regions of Turkey, the Adenovirus positivity rates were found by Tekin et al., [26] as $1 \%$ in Mardin, Altındis et al., [27] found as 4.5\% in Afyon, Albayrak et al., [28] found as 4\% in Ankara, Kurtoglu et al., found as 4.4\% [29], Otag et al., found as 3.3\% in Mersin [13], Balkan et al., found as $8.2 \%$ in Erzurum [25], Turkdag1 et al., and Findik found as 1.3\% in Konya [24]. In line with other studies in terms of Adenovirus rates, we found 20 patients $(0.37 \%)$ were positive. Although Adenoviruses, similar to Rotaviruses, are detected mostly in children aged 0-2 (11 patients, $55 \%)$, they can be an infectious agent in every season different from Rotaviruses which can be observed mostly in winter. 
Citation: Guckan R, Kllınc C, Aydin O, Durmaz ZH, Demir AD, et al. (2015) Rotavirus and Adenovirus Positivity in Child Diarrhoea in a Tertiary Hospital. J Infect Non Infect Dis 1:007.

- Page 3 of $4 \cdot$

\begin{tabular}{|c|c|c|c|c|c|}
\hline Viruses & Total (n) & Winter* (\%) & Spring (\%) & Summer (\%) \\
\hline Rotavirus & 395 & $173(43.7)$ & $118(29.8)$ & $25(6.3)$ \\
\hline Adenovirus & 20 & $6(30)$ & $5(25)$ & $9(45)$ \\
\hline Rota-Adeno & 7 & $1(14.2)$ & - & - \\
\hline
\end{tabular}

Table 2: Seasonal distribution of Rotavirus and Adenovirus positive diarrhea frequency.

*Winter (December, January, February), Spring (March, April, May), Summer (June, July, August), Autumn (September, October, November), n - Samples number, $\%$ - percent

Gastroenteritis may be caused by more than one microorganism simultaneously. Although bacteria-virus combinations can be seen, the most common one is the virus-virus combination [27]. In our study, Rotavirus-Adenovirus combination was observed together in 7 $(0.12 \%)$ patients and Otaget al al., found this rate as $0.76 \%$ in Mersin [13], Balkan et al., found as $0.3 \%$ in Erzurum [25] and Turkdag1 and Findik found as $1 \%$ in Konya [24]. Our results are also in line with the findings of other researchers.

Gastroenteritis is seen frequently in the childhood and it is more severe than the gastroenteritis observed in adults. These infections, which lead to high mortality and morbidity rates, are also a reason for a serious amount of economic losses. The determination of the main causative microorganisms for the childhood gastroenteritis, such as the age range and the diagnosis time of the disease, will be beneficial in the diagnosis, treatment and follow-up processes of these infections. According to our results, Rotavirus occurrence rate in Amasya was a little lower compared to the general rates of the infection detected in Turkey. Adenovirus occurrence rate was also calculated similar to the rates found in other studies performed in Turkey. Similar to the other, Rotavirus and Adenovirus infections are observed frequently in children aged 0-2. Although adenovirus positivity is similar in every season, Rotavirus positivity is particularly high in winter. In order to prevent the unnecessary antibiotic usage, further Rotavirus research is recommended in children who are admitted to the hospital with acute gastroenteritis complaints particularly in winter. It has been considered that studies will be more useful when the standardized methods are used and when the different types of samples from various geographical regions are included. Rotaviruses and Adenoviruses can be rapidly determined by the immune chromatographic tests by using stool samples.

\section{References}

1. Bass DM (2015) Rotaviruses, Caliciviruses and Astroviruses. In: Kliegen MR, Stanton B, St Geme J, Schor NF, Behrman RE (eds.). Nelson Textbook Of Pediatrics, Elsevier, Netherlands. Pg no: 11-37.

2. Yarkın F (2004) Gastroenteritis virüs. In: Ustacelebi S, Abacıoglu H. Badu $S$ (eds.). Molecular, clinical, diagnostic virology. Gunesbookstore, Ankara, Turkey. Pg no: 245-258.

3. Nazik H, İlktaç M, Öngen B (2006) Investigation Of Frequency Of Rotavirus İn Childhood Acute Gastroenteritis. Ankem Derg 20: 233-235.

4. Offit PA, Clark HF (2000) Rotavirus. In: Mandell GL, Bennet JE, Dolin R (eds.). Principles and Practice of Infectious Disease. (5thedn), Churchill, Livingstone, Philadelphia. Pg No: 1696-703.

5. Ozturk R (2004) Reovirus family and other gastroenteritis virus. In: Willke Topcu A, Soyletir G, Doganay M (eds.). Infectious Diseasesand Microbiology. (2ndedn), Nobel medical book store, Istanbul, Turkey. Pg no: 1564-1575

6. La Rosa AM, Champlin R, Mirza N, Gajewski J, Giralt S, et al. (2001) Adenovirus Infections in Adult Recipients of Blood and Marrow Transplants. CID 32: $871-876$.

7. Refik Saydam National Public Health Agency (2004) Burden Of Disease Final Report. National Burden Of Disease And Cost Effectiveness Project, Bașkent Unıversıty, Ankara, Turkey.
8. Bulut Y, İșeri L, Ağel E, Durmaz B ()2003 The Positivity of Rotavirus in Children with Suspected Acute Gastroenteritis. İnönü Üniversitesi Tıp Fakültesi Dergisi 10: 143-145.

9. İlktaç M, Șahin A, Nazik H, Öngen B (2012) Investigation Of Rotavirus Frequency And Following Up The Rotavirus Season Among Children With Acute Gastroenteritis: Evaluation Of Five-Year Results. Ankem Derg 26: 25-29.

10. Kizirgil A, Karakoçan S (2012) Detection of the ethiologic agents of the childhood acute gastroenteritis. Nobel Med 8: 60-65.

11. Borsa BA, Tokman HB, Cagatay P (2013) Determination of Rotavirus and Adenovirus Frequency Among 0-5 Year Old Children with Acute Gastroenteritis in Mardin Gynecology and Children Diseases Hospital. Ankem medical Journal. 27: 75-79.

12. Gül M, Garpardıç M, Çıragl P, Aral M, Karabber H, et al. (2005) İnvestigation of frequency of Rotavirus and Adenovirustypes 40/41 In children with gastroenteritis between 0-5 years of age. Ankem Derg 19: 64-67.

13. Otag F, Direkel S, Ozgur D, Delialioğlu N, Emekdaș G, et al. (2012) Investigation of rotavirus and enteric adenovirus antigens in pediatric patients with acute gastroenteritis by rapid immunochromatographic method. Mersin Üniversitesi Sağlık Bilimleri Derg 5: 18-23.

14. Yarkın F, Torun E, Tezi YL (2009) Molecular epidemiology of rotavirüs infections in children with acute gastroenteritis in our region. Microbiology $A B D$, Çukurova Üniversitesi Institute of Health Sciences. Thesis No: TF2008YL5, Adana, Turkey.

15. Mass G, Baumeister HG, Freitag N (1997) Viruses as causal agents of gastroenteritis in infants and young children. MMV Munch Med Wochenschr 12: 1029-1034

16. Begue RE, Gastanaduy AS (1999) Acute gastroenteritis virüses. In: Armstrong D, Cohen J (eds.). Infectious Diseases (1stedn). Mosby Harcourt Publishers, Barcelona, Spain. Pg no: 581-584.

17. Khalil K, Lindblom G-B, Mazhar K, Khan SR, Kajiser B (1993) Early childhealth in Lahore, Pakistan: VIII Microbiology. Acta Paediatr 82: 87-94.

18. Aihara M (1997) Infectious disease in Kenya--epidemiological study of diarrhoeal disease in children. Rinsho Byori. 45: 421-426.

19. Ahluwalia GS, Scott-Taylor TH, Klisko B, Hammond GW (1994) Comparison of detection methods from enteric clinical specimens. Diagn Microbiol Infect Dis 18: 161-166.

20. Hilmioglu S, Yüce K (1994) Investigation of Frequency of Rotavirus in Gastroenteritis. İnfection journal 8: 163

21. Ascı Z, Seyrek A, Kizirgil A, Ozen A, Yılmaz M (1996) Rotavirüs diarrhea in children in the $0-6$ age group to investigate the prevalence of ELISA and latex agglutination method. Infeksiyon derg 10: 263-5.

22. Inci A, Urhan B (2015) Frequency of Rotavirus in Children with Acute Gastroenteritis. Journal of Clinical and Analytical Medicine 6: 449-451.

23. Bicer S, Col D, Erdag GC, Giray T, Gural Y, et al. (2014) A Retrospective Analysis of Acute Gastroenteritis Agents in Children Admittedto a University Hospital Pediatric Emergency Unit. Jundishapur J Microbiol. 7: 9148.

24. Dağı HT, Fındık D (2014) Investigation of rotavirus and adenovirus antigens in patients with acute gastroenteritis. J Clin Exp Invest 5: 256-260.

25. Balkan CE, Çelebi D, Çelebi O, Altoparlak U (2012) İnvestigation of Rotavirus and Adenovirus Frequency Among 0-5 Years Old Children with Acute Gastroenteritis in Erzurum. Turk Microbiyology Community Journal 42: 51-54. 
Citation: Guckan R, Kllinc C, Aydin O, Durmaz ZH, Demir AD, et al. (2015) Rotavirus and Adenovirus Positivity in Child Diarrhoea in a Tertiary Hospital. J Infect Non Infect Dis 1: 007.

- Page 4 of 4 -

26. Tekin A (2010) The frequency of rotavirus and entericadenovirus in children with acute gastroenteritis in Mardin. J Clin Exp Invest. 1: 41-45.

27. Altındis M, Bestepe G, Ceri A, Yavru S, Kalaycı R (2008) Frequency Of Rotavirus And Enteric Adenovirus Infection in Children With Acute Gastroenteritis. SDÜ Týp Fak Derg 15: 17-20
28. Albayrak N, Caglayık DY, Altaș AB, Korukluoğlu G, Ertek M (2011) Evaluation of the results of acute viral gastroenteritis data in Refik Saydam National Public Health Agency, Virology Reference and Research Laboratory in 2009. Türk Hij Den Biyol Journal 68: 9-15.

29. Kurtoğlu MG, Inci A, Özdemir M, Baysal B (2010) Seasonal and Age Distribution of Adenovirus Gastroenteritis in Children. Türk Mikrobiyol Cem Derg 40: 157-162. 